\title{
Fritz Haber and His Institute
}

\author{
Gerhard Ertl
}

Dulce et decorum est pro patria mori

(It is sweet and honorable to die for one's fatherland).

This verse by Horace not only served during the First World War to stimulate the enthusiasm for the war. It is also the title of a poem by Wilfred Owen, which ends with the cry "the old lie!" Owen himself was killed as a young British volunteer just one week before the end of the war.

It was not only young men who were enthusiastic about the war in those days but also a large fraction of the university teachers and scientists. Among them was Fritz Haber with his maxim: "In peace for mankind, in war for the fatherland," - a philosophy that he adopted also for his institute, the recently founded Kaiser-Wilhelm-Institut für Physikalische Chemie und Elektrochemie, to which he had been appointed first director in 1911.

Two years earlier Haber had made his most important scientific discovery while still professor at the Technical University of Karlsruhe. While today, climate and energy are the greatest problems for mankind for which solutions are expected to come from science, in those days it was the need for food. As a consequence of progress in technology and medicine, the world population was growing so rapidly during the nineteenth century that, unless crops could be increased considerably by the development of artificial fertilizers, there was a great danger of famine. In a worldwide competition it was Fritz Haber who succeeded in 1909 in his laboratory to produce ammonia from nitrogen (from air) and hydrogen, which then could be readily converted into nitrogen fertilizers ("bread from air"). This reaction was then transferred within a surprisingly short period into a large-scale industrial process, now known as the Haber-Bosch process, by Carl Bosch and Alwin Mittasch at the BASF company, which started production in 1913. At present about 140 million tons of ammonia are produced this way every year, of which $90 \%$ are converted

\footnotetext{
G. Ertl $(\square)$

Department of Physical Chemistry, Fritz-Haber-Institut of the Max Planck Society in Berlin,

Berlin, Germany

e-mail: ertl@ fhi-berlin.mpg.de

(C) The Author(s) 2017

B. Friedrich et al. (eds.), One Hundred Years of Chemical Warfare: Research,

Deployment, Consequences, DOI 10.1007/978-3-319-51664-6_22
} 
into fertilizers. According to a realistic estimate, about one third of today's world population would starve if this source were not available.

Alfred Nobel decided in his testament that the prize named after him should be awarded to the person whose research had brought the greatest benefit to mankind. Under this viewpoint no one deserves this prize more than Fritz Haber, who received it immediately after the end of the First World War for the year 1918, despite international protests because of his role during the war. The Janus face of science becomes manifest in this context. Historians agree that without the Haber-Bosch process, the war would very likely have been over within less than a year, since the import of nitrates necessary for the production of explosives was blocked. This problem could be circumvented by the "saltpeter promise" ("Salpeterversprechen") of the German chemical industry, which was building large plants for the production of ammonia to be converted into explosives.

The general enthusiasm at the outbreak of the war also seized Fritz Haber, who became a volunteer like many other intellectuals. In a letter to his Swedish colleague S. Arrhenius he explained his reasons as follows:

... now we see it as our ethical duty, to take down our enemies with the use of all our strength and bring them to a peace that will make the return of such a war impossible for generations and give a solid foundation for the peaceful development of western Europe.

What an illusion, one can only say!

Haber followed this maxim not only personally, but also immediately converted the complete research program of his institute to military purposes. At the beginning the work concentrated on the development of alternatives for existing explosives, as for example the replacement of toluene, which could be used for the production of TNT. A severe accident happened in the laboratory on December 17, 1914, when a gifted young scientist, Otto Sackur, was killed and Gerhard Just, Haber's co-worker for many years, lost his right hand.

From the beginning of 1915 the work concentrated on problems of chemical warfare by poison gas, which was partly personally supervised by Haber at the front. On April 22, 1915 favorable wind conditions allowed the valves of containers filled with pressurized chlorine gas to be opened, thus causing the death or injury of many enemy soldiers. This military success prompted the emperor to promote Haber to the rank of Hauptmann (captain). In a state dominated by the military, this was an extraordinarily high distinction for him as a Jew.

A particularly tragic event has to be mentioned in this context. Haber's wife Clara Immerwahr, one of the very few female chemists at that time, lived in a broken marriage and also disagreed with the military activities of her husband. After a severe quarrel she shot herself with her husband's weapon during the night of May 2, 1915 in the garden of their home on the grounds of the institute. She was found dying by their 13-year-old son. Nevertheless, this did not prevent Haber from going to the front again the next day.

From then on the institute was the German center for research on poison gas and Haber became head of the chemistry department of the Ministry of War. His institute was transformed into a large-scale institution with 10 departments and up 
to about 150 scientists and engineers, for whom barracks were built and other rooms hired. The effect of poison gas became characterized by the Haber constant, that is, the product of concentration and duration of impact.

After the war, Haber went temporarily into hiding, and even grew a beard. The military activities were discontinued; later, Haber was even awarded the Nobel Prize. The institute rapidly returned to its normal research activities and experienced its "golden years" with world-class scientists such as Karl-Friedrich Bonhoeffer, James Franck, Herbert Freundlich and Michael Polanyi. Haber remained a patriot and tried to help his country with the immense reparations by starting a project in which gold was to be extracted from seawater, which, however, failed because of erroneous data analysis. His contribution to the foundation of an organization that was later to become the German Science Foundation (DFG) and the establishment of strong scientific contacts with Japan are two further examples for his outstanding organizational abilities.

After the seizure of power by the Nazis, Haber was forced by law to fire his Jewish collaborators. (He himself was exempted from this sanction because of his active participation in the war.) As a protest, he resigned from his position as director of the institute and died a broken man shortly afterwards (1934). In his testament he asked for a common gravesite together with his first wife Clara, which was then established in Basel.

Under the new government, fundamental research was rapidly abandoned and the projects were again concerned with military problems (however, no longer with poison gas), for which the institute was even honored with the title "NSMusterbetrieb."

There was another war during which many millions had to sacrifice their lives. In memory of this terror, Benjamin Britten composed his "War Requiem," for which he used poems by the above-mentioned Winfred Owen. And again we may quote a text from an ancient poet concerning the Thermopyles, which reads in the words of Schiller: "Wanderer kommst du nach Sparta, verkündige dorten, du habest uns liegen gesehen, wie es das Gesetz befahl" (Wanderer, if you come to Sparta, report thither that you have seen us lying here, as the law commanded). A shocking story by Heinrich Böll reports of a heavily injured young man who recognizes that he is lying in his former class room where he can still read the words on the blackboard: "Wanderer kommst du nach Spa...."

Today, we look back with satisfaction and gratitude on 70 years without war in Germany, during which the institute also continuously developed. In 1953, at the proposal of its then acting director Max von Laue, it was named after its first director in order to honor a great scientist and remember the injustice he suffered. Four years ago, the institute celebrated its centenary. During this period, among others, seven Nobel Prize winners worked at the institute. This glory is, however, tarnished by some dark stains, which have imbued later generations with sorrow and shame. 
Open Access This chapter is licensed under the terms of the Creative Commons Attribution-NonCommercial 2.5 International License (http://creativecommons.org/licenses/by-nc/ $2.5 /$ ), which permits any noncommercial use, sharing, adaptation, distribution and reproduction in any medium or format, as long as you give appropriate credit to the original author(s) and the source, provide a link to the Creative Commons license and indicate if changes were made.

The images or other third party material in this chapter are included in the chapter's Creative Commons license, unless indicated otherwise in a credit line to the material. If material is not included in the chapter's Creative Commons license and your intended use is not permitted by statutory regulation or exceeds the permitted use, you will need to obtain permission directly from the copyright holder.

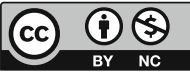

